ENTREPRENEURSHIP AND SUSTAINABILITY ISSUES

ISSN 2345-0282 (online) http://jssidoi.org/jesi/

2019 Volume 6 Number 4 (June)

http://doi.org/10.9770/jesi.2019.6.4(3)

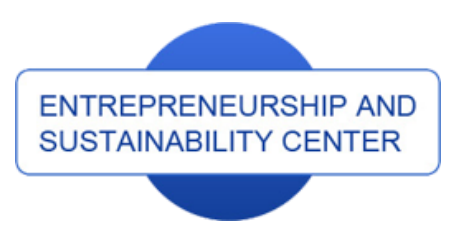

Publisher

http://jssidoi.org/esc/home

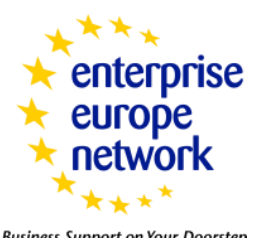

Business Support on Your Doorstep

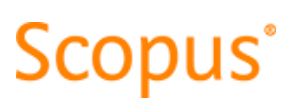

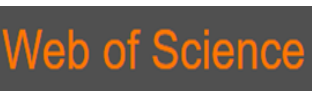

Clarivate

Analytics

\title{
COMPETITIVENESS OF HORTICULTURAL PRODUCTS AS A PRECONDITION OF INDUSTRY DEVELOPMENT
}

\author{
Olena Bohdaniuk ${ }^{1}$, Ruslan Buriak ${ }^{2}$, Vasyl Savchuk ${ }^{3}$ \\ ${ }^{1,2,3}$ National University of Life and Environmental Sciences of Ukraine, \\ Heroyiv Oborony Str. 15, 03041 Kyiv, Ukraine \\ E-mails.1 bogdaniuk.o.v@nubip.edu.ua ; ${ }^{2}$ ruslan1212@ukr.net $;{ }^{3}$ savchukvk@ukr.net
}

Received 18 December 2018; accepted 20 March 2019; published 30 June 2019

\begin{abstract}
Modern world globalization processes, a highly competitive environment and meeting the requirements of national interests, place new demands on the strategy of development of the horticultural industry in Ukraine, which should be aimed at increasing the competitiveness of fruit and berry products, its quality and environmental safety. Issues of competitiveness, quality and safety of agricultural products - are the most important among research of scientists, especially in developing countries. Improving the quality and safety of agricultural products is one of the main strategies for the development of agriculture in Ukraine; therefore, economic indicators are depreciated on the secondary plan: profit, profitability level, and the indicators of biological and social value of products become priority. That is why the main purpose of writing the article is to clarify and improve the indicators of assessing the competitiveness of horticultural products as a precondition for the development of the industry, its competitiveness. To achieve the research purpose the state of the industry, its competitive advantages was analyzed; an expert evaluation of the main parameters of the competitiveness of fruit and berry products was carried out, a survey was carried out by both producers and consumers of products on the importance of individual indicators in assessing the overall competitiveness of products. As a result of the conducted research, the methodology of evaluating the competitiveness of fruit and berry products with the account of biological, ecological, production and economic parameters was specified and the main technological stages of the formation of these indicators in horticulture were determined.
\end{abstract}

Keywords: competitiveness of products; horticulture; fruit and berry products; product quality; product safety; Ukraine

Reference to this paper should be made as follows: Bohdaniuk, O.; Buriak, R.; Savchuk, V. 2019. Competitiveness of horticultural products as a precondition of industry development, Entrepreneurship And Sustainability Issues 6(4): 1587-1601. https://doi.org/10.9770/jesi.2019.6.4(3)

JEL Classifications: E23, P32, Q12, Q18

Additional disciplines: ecology and environment 


\section{ENTREPRENEURSHIP AND SUSTAINABILITY ISSUES}

ISSN 2345-0282 (online) http://jssidoi.org/jesi/

2019 Volume 6 Number 4 (June)

http://doi.org/10.9770/jesi.2019.6.4(3)

\section{Introduction}

Horticulture can be considered as one of the most important branches of agricultural production in Ukraine due to the production of valuable fruit and berry products rich in vitamins and biologically active substances. The importance of horticultural products to meet the food needs of the population of Ukraine and its regions can not be overestimated, since fruits and berries are valuable and irreplaceable food products that are characterized by tread properties, which, due to the high content of pectin that extracts toxins from the body, including radioactive elements (Shestopal \& Ermakov, 1998), and the branch of horticulture is an important component of the country's economic and social development. Ukraine has all the necessary conditions for growing sufficient quantity and quality of fruit and berry products, but the experts' assessment of the industry is the basis for the conclusion that Ukrainian horticulture by most indicators is not able to compete with the level of development of this industry in Europe.

Modern world globalization processes, a highly competitive environment and meeting the requirements of national interests place new demands on the development strategy of the domestic industry. In particular, the situation has changed since January 2016, with the entry into force of the Agreement on a Deep and Comprehensive Free Trade Area between Ukraine and the European Union. On the positive side - domestic producers of horticultural products have opened new opportunities for exporting products to EU countries, from the negative - insufficient competitiveness of Ukrainian fruit and berry products in the markets of Europe, both qualitative parameters and development potential, as in many European countries, horticulture - the strategic sector of the economy, which is supported by the state. In such a situation domestic producers of horticultural products were in unequal conditions with foreign producers: high standards of quality of European agricultural products, non-compliance with quality standards and control, lack of proper logistical support, imperfect Ukrainian cultivating technology and diverse horticultural products of competitors threaten the domestic market of gardening products. Alongside with this, European countries, nevertheless, are not without reason, see Ukraine as a potential competitor, because our country has potential advantages for the production of ecologic fruit and berry products and take an important place in the markets of Europe.

\section{Literature review}

The issue of improving the competitiveness of the industry, the main strategic and innovative priorities of horticulture development are considered in the works of domestic and foreign scientists. In particular, in his research, Kondratenko (2017) focuses on the need for innovations in horticulture, through the elimination of immune-resistant varieties of fruit and berry products, the cultivation of which will allow to obtain more ecological safety horticultural products (p. 122).

Improvement of the method for assessing the competitiveness of horticultural products is devoted to a number of works by Rul'ev (2007), in particular in his monograph (p. 109), the author draws attention to the fact that the assessment of the competitiveness of pomological varieties of fruit crops is recommended to be carried out in soilclimatic zones, taking into account their natural features, which directly affects the quality and quantity of the fruit and the price of the product.

The main strategic and innovative priorities of hoticultural development in Ukraine are researched in the works of Kushniruk (Kushniruk et al., 2009), where it is noted that the increase of efficiency and competitiveness of horticulture should be based on its consistent intensification, which provides deepening the specialization and concentration of the industry and transfer to the innovative and investment way of development (p. 3). 


\section{ENTREPRENEURSHIP AND SUSTAINABILITY ISSUES}

ISSN 2345-0282 (online) http://jssidoi.org/jesi/

2019 Volume 6 Number 4 (June)

http://doi.org/10.9770/jesi.2019.6.4(3)

Increasing the competitiveness of domestic horticulture depends on its scientific support (Shestopal et al., 2008): "The research area should focus on the market for the latest developments, study the demand for scientific products, create such technologies that, in the conditions of the economic crisis, would meet the criteria of efficiency, were low-cost, resource-saving and environmentally safe. This necessitates the creation of innovative products in the industry in accordance with the requirements of the market for science-intensive products" (p. 126). Gutorova (2013) emphasizes that "to ensure the production of horticultural products of a guaranteed quality and to protect consumers' interests, it is necessary to improve the national system of certification and standardization of food products, planting material, as well as a system of sanitary control (covering also imported products), which should find the place of control of the timeliness and completeness of all technological operations during the production of fruits, berries and seedlings in different regions of Ukraine" (p. 139). The question of changing the market condition of horticultural products under the influence of globalization processes was considered in the works of Karpenko et al. (2016). Rul'ev (2004) notes that the economic components of the prospects for the development of industries, in particular, regarding the rational allocation and specialization of the production of certain types of products, can only be justified by the qualitative consideration of the correspondence of soils, climate and relief to the biological requirements of agricultural crops (p. 6). Given the diversity of the climate of Ukraine, Kondratenko et al. (1999) argued about the importance of zoning of horticulture and the establishment of an orchard variety of fruit and berry crops. Therefore, there was and is in the country an extremely topical problem of zonal specialization in horticulture, rational territorial placement of production of specific types of fruits and berries.

Modern researches of foreign authors, for the most part, focus on the application of innovative technologies in horticulture and their impact on the environment, ecology, society. In particular, among the foreign authors who studied the competitiveness of horticulture should be identified Pushkarik et al. (2009), studied the problems of producing high quality horticultural products in Europe as in general, and in Serbia as in particular. Scientists Van den Broek and Myet Martins focused on studying the relationship between the volume of production and export of gardening products and food security in developing countries. (Goedele Van den Broeck \& Miet Maertens, 2016). Angeles Godoy-Duran et al. devote their work on the effectiveness of eco-gardening in Spain (2017). The issues of the competitiveness of Polish horticulture are considered in the works of Polish scientists, among which the following scientists should be distinguished: Jablonska, Filipiak, Gunerco. Scientists have proved the importance of constant control of costs in horticulture in order to ensure its competitiveness (Lilianna Jablonska et al., 2017). Issues of determining factors driving sustainable performance through the application of lean management practices in horticultural primary production were explored by Darian Pearcea, Manoj Dorab, Joshua Wesanaac \& Xavier Gellyncka (Darian Pearcea et al., 2018). Analyzing recent publications and researches of both foreign and domestic authors, it should be noted that the interest in issues of innovative technologies of fruit and berry production, which would ensure high competitiveness of products, increased its ecological and socioeconomic value of the industry should be noted. Considering the importance of horticulture as a key industry that provides food security to the country, the environmental and social component of its development, there is a need for further methodological developments and practical recommendations on improving the competitiveness of domestic horticultural products as a priority for strategic development of the industry. The key point of research should be the development of measures that ensure the high quality of horticultural products, its compliance with standards, environmental safety. So, economic indicators: profit, profitability level go down to the secondary plan. Priority is given to indicators of biological and social value of products: the biological value per unit of the spent resource and the share of labor costs in the cost of production etc. Accordingly, indicators for assessing the competitiveness of fruit and berry products need to be substantially refined.

\section{Aim}

The main purpose of the article is to clarify and improve the indicators for assessing the competitiveness of horticultural products as a prerequisite for the development of the industry. 


\section{ENTREPRENEURSHIP AND SUSTAINABILITY ISSUES}

ISSN 2345-0282 (online) http://jssidoi.org/jesi/

2019 Volume 6 Number 4 (June)

http://doi.org/10.9770/jesi.2019.6.4(3)

\section{Data and Methods}

During writing of the article we used both general science methods, and applied methods of research. In the study of economic processes, national legislation, works of domestic and foreign authors we used systematic and complex approaches, a combination of historical and logical methods.

The first part of our research is aimed at assessment of the current state of Ukrainian horticulture and its competitiveness. To study this issue we used dialectical method of cognition, induction and deduction, trend analysis, comparative analysis.

The second and the third part of the study are aimed at improvement of evaluation indicators of the competitiveness for fruit and berry products The evaluation of the competitiveness of horticultural products was carried out through a comparative analysis using the classical theory of "Effective competition" J. Alois Shumpeter (1983), according to which effective competition is possible only in a dynamic economy, innovation. The theory of "Premises of the Corporative Strategy", Michael E. Porter (1987), has been taken into consideration, according to which any successful corporate strategy builds on a number of premises.

For evaluation the competitiveness of horticultural products we used a score assessment (methodology of the annual Global Competitiveness Report, Global Economic Forum, 2018). Biological, ecological and economic parameters of the competitiveness of a separate apple variety were determined on the basis of research by scientists-pomologists.

To justify the parameters of the competitiveness of horticultural products we used assessments of industry experts. Consumers and producers survey were carried out on the level of significance of individual parameters in the calculation of the general competitiveness of horticultural products (Table 3). The survey was conducted among producers and consumers of horticultural products in Podillya (Khmelnytsky and Vinnytsia regions), the region that holds the largest share in the total production of fruits and berries in Ukraine. Among the producers were selected 15 main farms engaged in the cultivation of fruit and berry products, consumers — the local population (527 consumers of different age groups participated in the consumer survey). Despite the small percentage of the sample $(0.02 \%)$, we tend to consider the results of the survey as reliable, since the total share of Vinnitsa and Khmelnitsky districts in the total volume of production of fruit and berry products in Ukraine is almost 40 percent (State Statistic Service of Ukraine, 2017). The detailed information about the Respondents is presented in Table 1.

Table 1. Respondents' characteristics (consumers)

\begin{tabular}{lcc}
\hline Age range & Number of respondents & Percentage $(\%)$ \\
\hline $15-25$ & 54 & 10 \\
$25-34$ & 125 & 24 \\
$35-44$ & 212 & 40 \\
$45-54$ & 136 & 26 \\
$55-64$ & 54 & 10 \\
more than 65 & 125 & 24 \\
\hline
\end{tabular}

Source: The authors' own calculations based on survey of producers and consumers of horticultural products in Podillya

During the study we used data from the State Statistics Service of Ukraine for the period from 2010 to 2017; Eurostat data on the volume of organic garden production in the EU; information of organic producers in Ukraine "Organic Ukraine"; information of specialists of the branch, in particular the associations of producers of 
horticultural products "Ukrsadprom"; domestic and foreign studies of scientists who studied the current state and trends of development, competitiveness of the horticultural industry.

\section{Results}

Assessment of the current state of Ukrainian horticulture and its competitiveness. Horticulture of Ukraine is one of the main branches of agricultural production, which provides the needs of the population in finished products, industry — processing raw materials, rural areas — workplaces.

Ukraine, which apples are one of the main crops, is ranked 12th in the world ranking, with a production volume of 3.3 million tons. The share of output of fruit and berry products in the total output of crop production was $3.22 \%$ in 2010 and $2.92 \%$ in 2016 (Table 2).

Table 2. Value of horticultural production in Ukraine

\begin{tabular}{lccc}
\hline \multicolumn{1}{c}{ Indexes } & 2010 & 2015 & 2016 \\
\hline Gross production of fruits and berries, mln & 9633 & 18390 & 18262 \\
UAH & 1079346 & 1988544 & 2385367 \\
GDP, mln UAH & $\mathbf{0 . 8 9}$ & $\mathbf{0 . 9 2}$ & $\mathbf{0 . 7 6}$ \\
Share in GDP, \% & 298984 & 532257 & 625585 \\
Gross output of agriculture, mln UAH & $\mathbf{3 . 2 2}$ & $\mathbf{3 . 4 5}$ & $\mathbf{2 . 9 2}$ \\
Share in Gross output of agriculture, \% & & & \\
\hline
\end{tabular}

Source: The authors' own calculations based on data of State Statistics Service of Ukraine (2017)

Horticultural experts have proved that for the successful development of the industry, its competitiveness both must be taken into account economic and natural factors. Assessing the competitive advantages of horticulture in Ukraine by natural factors, we note that the state has sufficient advantages over European countries in terms of soil and climatic conditions, but, unfortunately, it is not fully use these advantages yet, since, in the first place, the existing constraints are the economic preconditions.

Lack of proper financing of the industry and state support, necessary logistical support and material motivation of employees; high complexity and cost of production; the discrepancy between the selling price and the production unit cost price, the unregulated market for horticultural products and the lack of scientific support of the industry led to negative trends in horticulture. According to the State Statistics Service of Ukraine (Ukrstat), for the period from 2011 to 2017 there is a gradual decrease in the area under fruit and berry plantations in the fruiting age: annually by 5.13 thousand hectares in all categories of farms, which is mainly due to the reduction of the area of plantations in agricultural enterprises, an average of 4.23 thousand hectares for the analyzed period (Graph 1). 


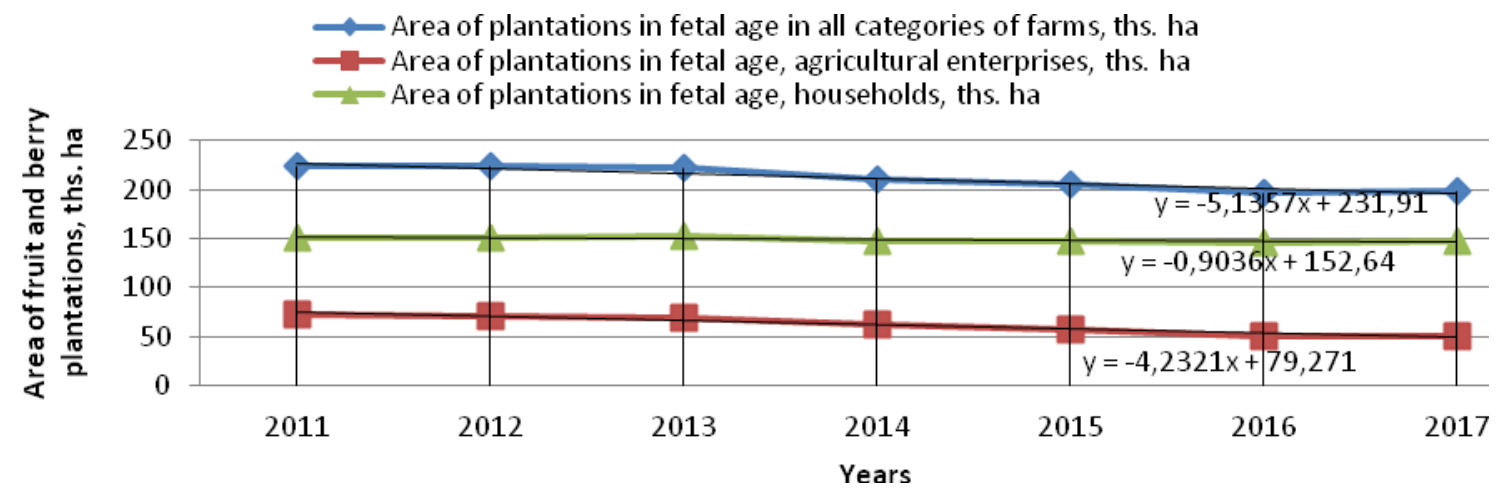

Graph 1. Dynamics of areas under fruit and berry plantations in Ukraine

Source: The authors' own calculations based on data of State Statistics Service of Ukraine (2017)

Together with the annual reduction of areas under fruit and berry crops, there is an increase in the yield of horticultural products, which has a positive trend: the yield of fruit and berry crops, in all categories of farms, increased by an average of $2.84 \mathrm{c} /$ ha for the analyzed period. However, there is a significant variation in yield. The average yield of fruit and berry crops during 2011-2017 at agricultural enterprises is 40.1 centners per hectare, while in the households is 108.5 centners per hectare (Graph 2).

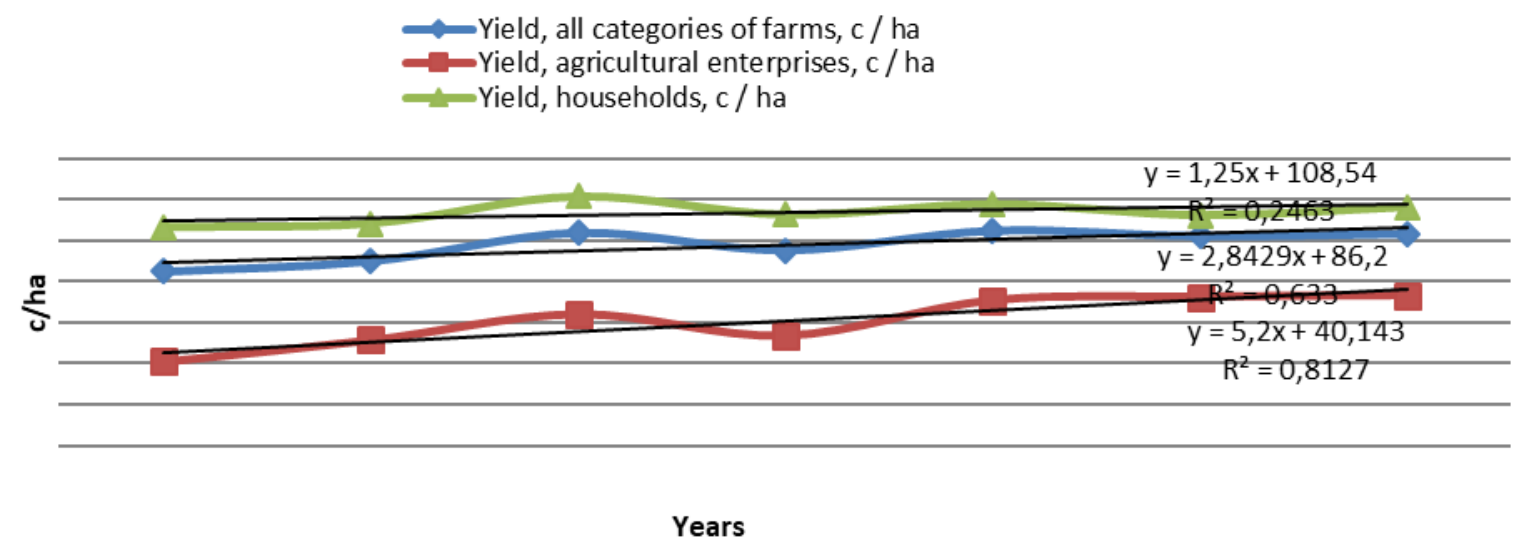

Graph 2. Dynamics of yield of fruit and berry plantations in Ukraine

Source: The authors' own calculations based on data of State Statistics Service of Ukraine (2017)

The unstable political, economic situation in the country and the high cost of horticultural production have led to the fact that horticulture in Ukraine is generally low-profitable. The profitability of fruit production, according to Ukrstat, in agricultural enterprises in 2016 amounted to 12\%, including: in business partnerships - 11\%, private - $22.3 \%$, state - $11.7 \%$ (Ukrstat, 2016). The situation with berries is slightly better, where the average profitability in agricultural enterprises is 104 percent.

The assessment of the state of the industry also suggests that horticulture of Ukraine in recent years has been concentrated mainly in households and small farms with higher productivity and profitability. The obtained higher yields in households, compared to agricultural enterprises, indicate a better organizational and agronomic work of 


\section{ENTREPRENEURSHIP AND SUSTAINABILITY ISSUES}

ISSN 2345-0282 (online) http://jssidoi.org/jesi/

2019 Volume 6 Number 4 (June)

http://doi.org/10.9770/jesi.2019.6.4(3)

managers, better technical and financial support, the use of high-yielding planting varieties, etc. Thus, one of the trends in the development of Ukrainian horticulture is the process of gradual reduction of industrial horticulture. In our opinion, this situation does not contribute to the improvement of the state of the industry, and, moreover, to increase its competitiveness, as there are factors of both economic and mental character, in particular: lack of competence in horticultural matters; insufficient material, technical, technological support; non-compliance with the production technology, resulting in deterioration of the environmental situation, the quality of the products produced, its ecologic.

The need to increase the competitiveness of fruit and berry products. In order to enter the foreign markets, horticultural products must meet certain quality standards, be safety and biologically valuable - only such products can take their place among competitors.

For comparison, in the European Union, today, according to Eurostat, more than 300 thousand hectares of organic gardens, half of which - in Poland, France, Italy. In addition, 24.2\% of all organic farms in the EU grow fruits (Antonella De Cicco, 2016). According to a union of producers of organic products "Organic Ukraine" (2017), European companies are interested in organic horticultural products and see in Ukraine a great potential for the production of organic products. However, for today, only 15 companies that are engaged in organic production are certified in Ukraine, 7 of them specialize in the cultivation of organic apples. Thus, under organic production in Ukraine occupied $0.15 \%$ of traditional gardens.

The modern Ukrainian market is full of imported products, which creates competition for domestic. However, not all imported products are qualitative, but in such a way as to meet the requirements of standards and dietary nutrition.

Chinese scientists Yao Yuchen et al. argue that modern means of protecting crops and chemical fertilizers are so aggressive that it is not always possible to ensure the proper quality and safety of products (2013). They prove that a large number of fruits and berries in the world market have been grown and stored in a non-natural way, which means that during growing, farmers used ripening and growth boosters of fruits and berries; sellers, for their part, used chemicals for storage, such as "formaldehyde", "formalin", and so on. These chemicals are hazardous and can cause significant harm to the human body and are dangerous. That is why the issue of quality and safety of agricultural products is among the key issues in the scientific research of the world, and the quality indicators of the effectiveness of the assessment of output, in our opinion, must dominate the indicators of economic efficiency.

According to Shpichak (2010) "the quality of agricultural products is one of the most difficult categories with which humanity faces in the process of material production. The level of product quality affects the price, costs, the level of gross output of the finished product, productivity, profitability, product competitiveness, and ultimately - the health and life expectancy of a person" (p. 11). Consequently, quality plays a great role in the system for assessing the competitiveness of products. It is important to share the concept of quality and safety of food products. Food safety $(\mathrm{CAC}, 2005)$ - assurance that food will not cause harm to the consumer when it is prepared and/or consumed according to its intended use. Food quality (ISO, 22000:2018) —- the totality of features and characteristics of a product that bear on its ability to satisfy stated or implied needs.

The system of quality and food safety management in Ukraine is mandatory for the implementation and functioning, regulated by Law of Ukraine "On Basic Principles and Requirements for Food Safety and Quality" (1998). The purpose of the Law is to facilitate the active introduction of Hazard Analysis and Critical Control Points (HACCP) at the domestic enterprises of the international system for controlling the safety and quality of food products. However, the authors of the study point out that for the implementation of the concept of HACCP in the production of horticultural products, there are certain restraining factors in the country, among which are: the concentration of production of fruit and berry products, mainly in households where it is impossible to control the production process in full ; low selling price, which does not cover additional costs for product quality. 


\section{ENTREPRENEURSHIP AND SUSTAINABILITY ISSUES}

ISSN 2345-0282 (online) http://jssidoi.org/jesi/

2019 Volume 6 Number 4 (June)

http://doi.org/10.9770/jesi.2019.6.4(3)

Improvement of evaluation indicators of the competitiveness for fruit and berry products. Considering agricultural products, we should highlight its uniqueness, which makes it distinct among the products of the industry. Therefore, when we talk about its quality, it is important to focus not only on environmental performance but also on the biological and ecological value of cultivated produce.

In addition to the qualitative characteristics to assess the competitiveness of products includes other factors. It is known, that competitiveness is a comparative characteristic of products, which contains a comprehensive assessment of the whole set of production, commercial, organizational and economic indicators. It is determined by the aggregate of consumer properties of the given product by the degree of compliance with social needs, taking into account the costs of their satisfaction, prices, conditions of supply and operation in the process of production or personal consumption.

The conditional formula for the competitiveness of a particular product type can be represented as a set of qualitative and cost characteristics of products that contribute to the creation of the benefits of the parameters of this product to the competitors' products in meeting the specific needs of the consumer (1):

$$
C=\frac{\text { quality }}{\text { price }} \rightarrow \max
$$

In this interpretation, the competitiveness indicator $(C)$ reflects the proportion of product quality per unit of its price. However, the researched indicator is determined by the ratio of the beneficial effect (only a certain part of quality) to the total costs associated with the acquisition and exploitation of products. Consequentially, in the consumer's understanding, such a correlation should go to its maximum value.

The buyer substantiates the choice of products, assessing the beneficial effect of its use and the costs associated with its purchase and use (2):

$$
C=\frac{E e_{i}}{P c_{i}} \rightarrow \max
$$

where $E e_{i}$ - an economic (beneficial) effect of consumption of the $i$-th product; $P c_{i^{-}}$total expenses of the consumer on purchase and consumption of the $i$-th product in the conditions of a specific market.

The filling of the modern Ukrainian market with high-quality, competitive fruit and berry production of domestic production is possible due to the introduction in Ukrainian gardens of domestic and foreign breeding varieties, which are characterized by high commodity and taste qualities of fruits, as well as high adaptability to the conditions of a particular zone. The long-term studies of breeders and pomologists determined that for the Foreststeppe Ukraine (the forest-steppe stretches from the Southwest from the border with Moldova to the Northeast to the border with Russia through the central part of the country, 33\% of the territory of Ukraine), such are Askolda, Amulet, Gala Mast, Johnogold de Costa, Delicia, Katerina, Karazinskaya, Mavka, Melrose, Radogost, Teremok, Edera. The yield of these varieties in 4-8-year-old plantations of intensive type reaches 22-60 t/ha. Tasting appraisal of the taste and quality of the fruits is 4.4-4.9 points.

Exploring the characteristics of a particular variety of fruits and berries, we came to the conclusion that some varieties fully meet the needs of both producers and consumers. The results of an expert evaluation of apple varieties indicate the biological importance of a single variety that affects the level of expenditure (for example, disease resistance, transportability, early entry into commodity fruiting), the level of sales price (for example, taste, appearance, size of the fruit), and respectively, on the quality of the fruits (reducing the amount of chemical spraying, the content of vitamin $\mathrm{C}$, pectin, etc.) (Table 3). 
This assertion gives grounds to conclude that the initial qualitative and cost indicators of production are laid at the stage of creating a separate variety — geneticists, breeders. The seeded cultivar, the cultivated plant that has improved disease and pest resistance rates, better quality characteristics, will have advantages over other, less competitive varieties. The issues of product adaptation capabilities in an emerging market context were studied by Rejie George et al. (2018).

Experts in the industry prove that the use of high-immunity fruit crops is: saving up to $70-75 \%$ of the costs required for plant protection; high commodity quality of the obtained fruits; a simplified scheme for protecting the garden from pests and diseases (spraying up to 6 times a year); $30 \%$ more healthy fruits; high productivity, stable harvests; unpretentiousness of plants to climatic conditions, which allows to grow products throughout the territory of Ukraine; frost resistance; products that meet international standards; reduction of anthropogenic impact on the environment.

Table 3. Biological and ecological indicators of competitiveness of some apple varieties that are common in Ukraine

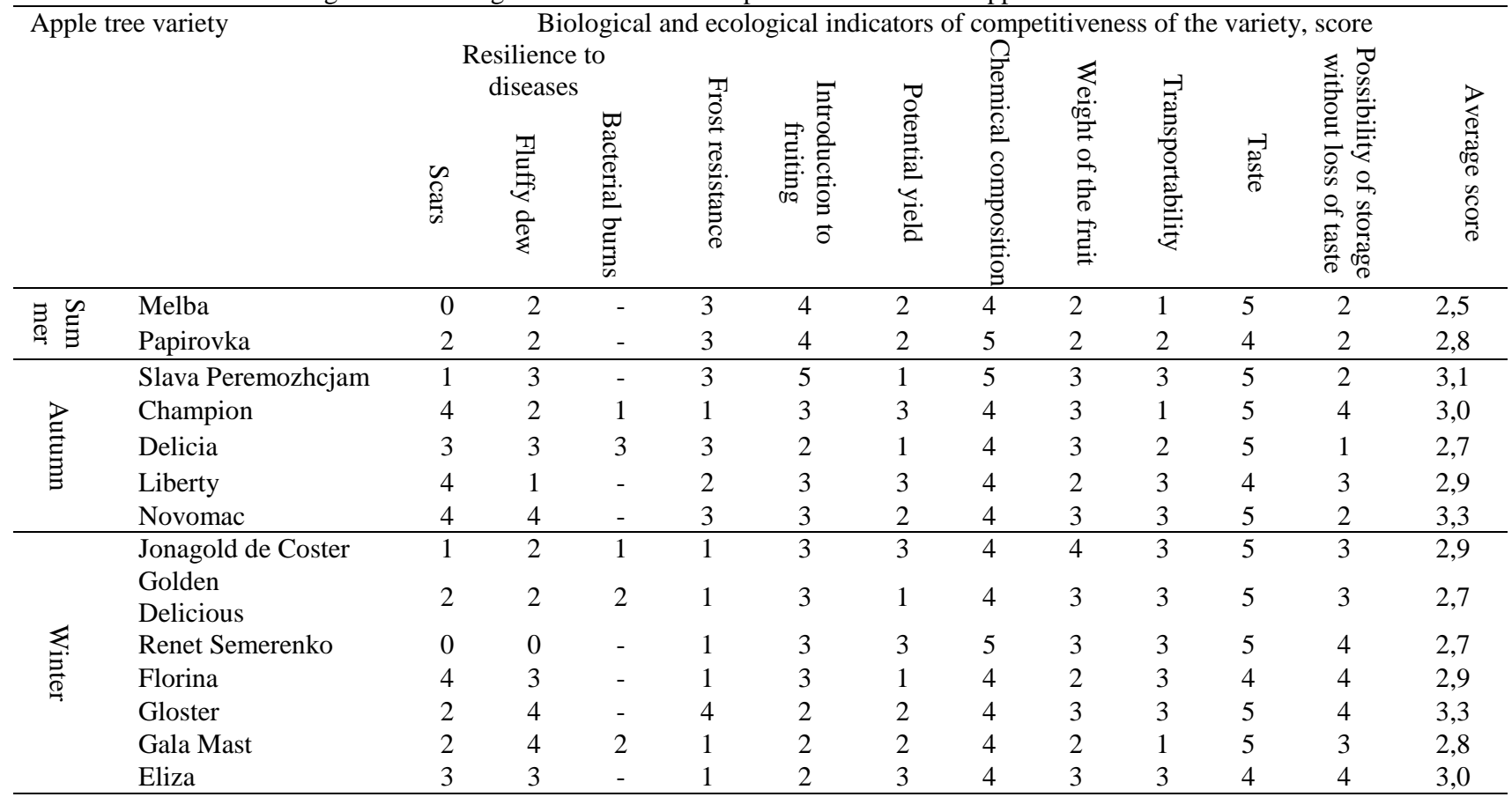

Source: The authors' own calculations based on evaluation of industry experts, characteristic of a separate variety 
ENTREPRENEURSHIP AND SUSTAINABILITY ISSUES

ISSN 2345-0282 (online) http://jssidoi.org/jesi/

2019 Volume 6 Number 4 (June)

http://doi.org/10.9770/jesi.2019.6.4(3)

\section{Biological and ecological indicators of competitiveness of some apple varieties that are common in Ukrane, were culculated by the following methods:}

Resilience to diseases on the scale 0-4: 0- very affected, 1- affected, 2 - moderately affected, 3 - weakly affected, 4 - resistant, and «-» is absent.

Frost resistance and winter stability on a scale of 0-3: 0 - unstable, 1 - medium resistance, 2 - stability above average, 3 - high stability.

Introduction to fruiting on a scale of $0-4$, depending on the year: on $6-0$, on $5-1$, on $4-2$, on $3-3$, on $2-4$.

Potential yields on a scale of 0-4: up to $40 \mathrm{~kg}$ per tree- $0,40-60 \mathrm{~kg}$ per tree $-1,60-80 \mathrm{~kg}$ per tree $-2,80-100 \mathrm{~kg}$ per tree -3 , over $100 \mathrm{~kg}$ per tree -4 .

The chemical composition is estimated by the author depending on the content of pectin and vitamin $\mathrm{C}$ in $100 \mathrm{~g}$ of raw mass on a scale of 0-4, depending on the weight of the fruit: small (16-70 g) - 0, smaller than average (71-110 g) -1, average size (111-150 g) -2, larger than average size (151- 200g) - 3, large (201-350g) - 4 .

Transportability on a scale 0 -3: 0- not transportable, 1 - average transportability, 2 - transportability higher than average, 3 - high transportability.

An expert assessment of the taste of fruits is approximated by the authors to an integer.

The duration of storage is estimated on a scale of $0-4$, depending on the number of storage date for three groups (summer, autumn, winter).

In the process of growing, harvesting, storing and transporting, only compliance with and improvement of the qualitative indicators of the competitiveness of fruit and berry products takes place. The process of forming and improving the competitiveness of fruit and berry products can be reflected in stages (Figure 1).

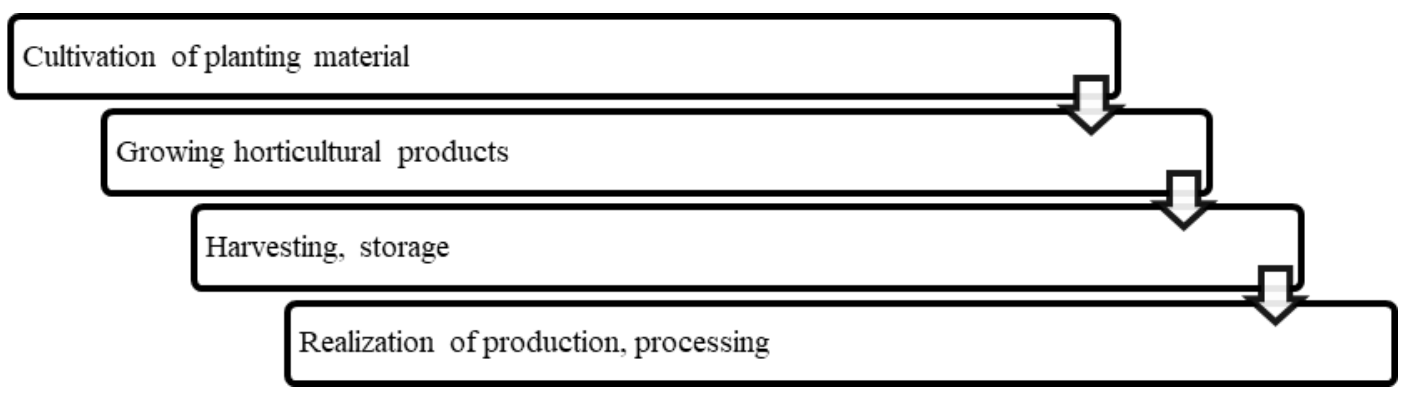

Figure 1. Technological stage-by-stage process of formation, observance and improvement of indicators of competitiveness of horticultural products. Source: Development by authors

According to the existing classical technique of product competitiveness it is not fully reflect all the parameters of the competitiveness of horticultural products, and therefore should be revised and improved. We consider it necessary to specify quantitative and qualitative parameters that are included in the formula for calculating the level of competitiveness of horticultural products.

The general indicator of competitiveness of horticultural products is an integrated indicator of competitiveness (3): 


$$
I_{c(j)}=\frac{I_{b l(i)} \cdot I_{e g(i)} \cdot I_{p r_{(i)}}}{I_{e c(i)}},
$$

where $I_{c(j)}$ — the integrated index of competitiveness of the analyzed pomological variety of horticultural product (i) in relation to the sample variety; $I_{b l(i)}$ - group indicator for biological parameters; $I_{e g}$ (i) - group indicator for ecological parameters; $I_{p r(i)}$ - group indicator for production parameters; $I_{e c(i)}$ - a group indicator for economic parameters (cost of consumption).

The biological characteristics should include indicators that depend on a set of actions of cultivation and growing of fruit-bearing plantations, for example: resistance to diseases, frost resistance, the period of introduction into fruiting, yields, etc. The ecological characteristics should include the parameters contained in the normative documents, standards and reflect the requirements of technical, environmental, moral and ethical safety of products: color, taste, chemical composition. Production and economic parameters of production form its production cost at the enterprise.

Group indices are single, and their value is calculated as an additive form of a complex indicator with weight coefficients. The formula for horticultural products will look like (4):

$$
I_{g r(j)}=\sum_{i=1}^{n} q_{i(j)} \times a_{i}
$$

where: $I_{g r(j)}$ is a group index of a separate pomological variety; $q_{i(j)}$ is a unit parametric index for the $i$ parameter of the $j$ pomological variety; $a$ - the weight of the $i$ parameter; $n$ - number of parameters being analyzed.

After conducting surveys of specialists of the industry, and consumers of products that evaluated the qualitative characteristics of a particular variety on a five-point scale, we determined the ranking of competitiveness indicators for the producer and consumer. Taking as a basis the methodology for calculating the competitiveness used during the compilation of the Global Competitiveness Report, we calculated the points. Estimated values are rounded by the authors to an integer.

Calculated average quality

indicators of a separate variety of apples are converted to the corresponding weighting factor according to the following method: the average score " 0 " is the weight coefficient - 0.25 ; average score "1" — weighted coefficient — 0.5; average score "2" — weight factor — 0.75; average score " 3 " — weighted coefficient — 1; the average score is "4" — the weight factor is 1.25 ; the average score is "5" — the weight factor is 1.50 .

In accordance with this method it is possible to calculate the competitiveness of a separate apple variety for producer and consumer (Table 4). 
Table 4. Method of determining weight coefficients of quality indicators of a separate variety for producer and consumer, scale of assessment from 0 to 5 points

\begin{tabular}{|c|c|c|c|c|}
\hline \multirow[t]{2}{*}{ Qualitative indicators of competitiveness } & \multicolumn{2}{|c|}{ Producer } & \multicolumn{2}{|c|}{ Consumer } \\
\hline & $\begin{array}{c}\text { average score on } \\
\text { the results of the } \\
\text { survey }\end{array}$ & weight factor & $\begin{array}{c}\text { average score on } \\
\text { the results of the } \\
\text { survey }\end{array}$ & weight factor \\
\hline Yield & 5 & 1.50 & 0 & 0.25 \\
\hline Introduction to fruiting & 5 & 1.50 & 0 & 0.25 \\
\hline Expiration date & 5 & 1.50 & 3 & 1.00 \\
\hline Taste, color & 4 & 1.25 & 5 & 1.50 \\
\hline Resistance to scab & 5 & 1.50 & 0 & 0,25 \\
\hline Weight of the fruit & 4 & 1.25 & 4 & 1.25 \\
\hline Transportation ability & 3 & 1.25 & 3 & 1.00 \\
\hline Resistance to powdery mildew & 4 & 1.25 & 0 & 0.25 \\
\hline Resistant to bacterial burns & 3 & 1.00 & 0 & 0.25 \\
\hline Chemical composition & 3 & 1.00 & 5 & 1.50 \\
\hline Frost resistance & 4 & 1.25 & 0 & 0.25 \\
\hline
\end{tabular}

Source: Own calculations based on the survey of specialists of the industry, consumers of products

The system of phased evaluation of horticultural production, which makes it possible to assess the impact of basic biological, ecological, production and economical parameters of horticultural products on the level of its competitiveness, includes: the basic physiological stages of production and the maintenance and control of the formation and improvement of its indicators (Figure 2).

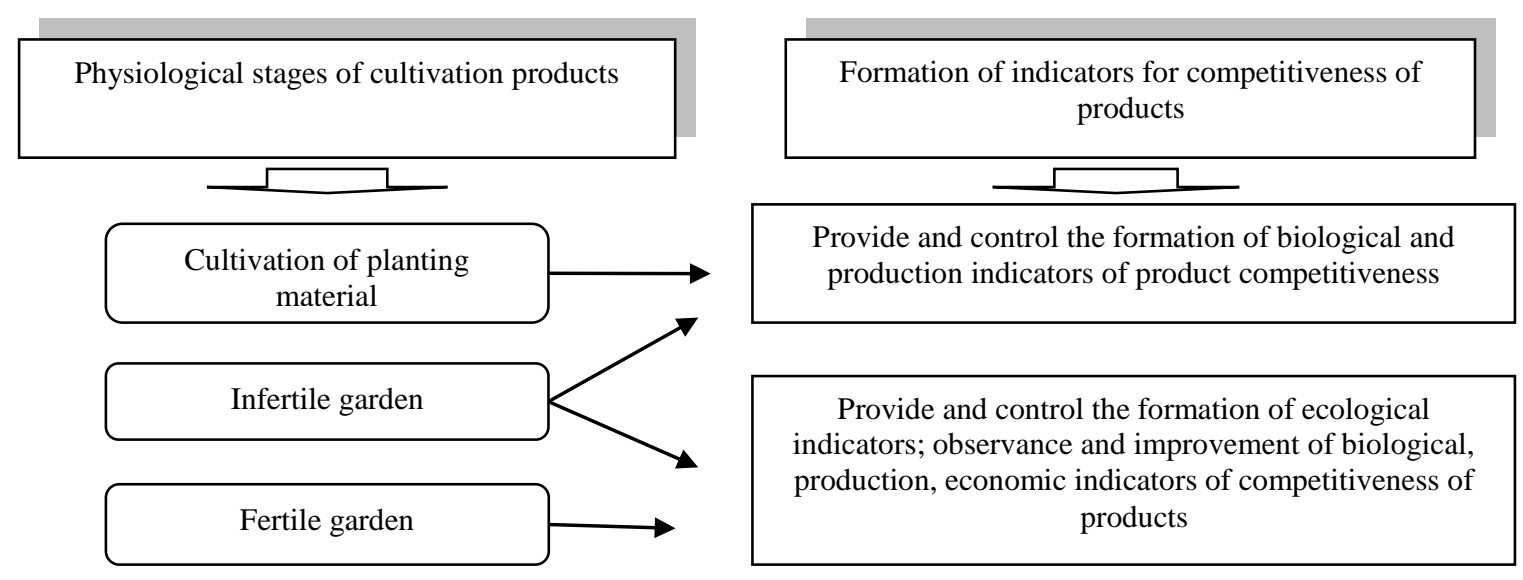

Figure 2. Formation of competitiveness of horticultural products

Source: Development by authors

The proposed method for evaluating the competitiveness of fruit and berry products will increase its competitiveness, quality and biological value, as it takes into account the output of biological, ecological and production value per unit of spent resource.

Kondratenko (2000) concluded that the fruits of varieties of summer and autumn ripening, grown mainly in Polissya and Forest-steppe of Ukraine, have a stable and equivalent taste due to the content of almost equal number of basic organic substances and the same ratio of sugars and acids. However, we cannot say the same about the apples of Golden Delicious and Renet Semerenko, their biochemical composition and taste varies 


\section{ENTREPRENEURSHIP AND SUSTAINABILITY ISSUES}

ISSN 2345-0282 (online) http://jssidoi.org/jesi/

2019 Volume 6 Number 4 (June)

http://doi.org/10.9770/jesi.2019.6.4(3)

according to the region of cultivation. Therefore, in order to ensure the competitive production of horticultural products, the genetic potential of each individual variety and the compliance with its soil and climatic conditions in the region must be fully taken into account. This approach will allow producers to some extent control the costs and prices of horticultural products.

\section{Conclusions}

The current study analyzes the competitiveness of horticultural products in Ukraine. The assessment of the industry indicates unsatisfactory trends in the development of domestic horticulture, which does not contribute to its competitiveness. In order to enter the foreign markets, horticultural products must meet certain quality standards, be safety and biologically valuable — only such products can take their place among competitors.

It was investigated that the importance in the process of forming the competitiveness of horticultural products is given to a separate variety. The evaluation of the biological and ecological indicators of competitiveness points to the advantages and disadvantages of a separate apple variety. Taking into account the importance of qualitative indices of a particular variety for the formation of the general competitiveness of horticultural products, we suggested an improved methodology for evaluating the competitiveness. We suggested calculating indices of competitiveness of horticultural products to include ecological, biological, production and economic parameters of competitiveness. The research also highlighted the industry stages of the formation, observance and improvement of the competitiveness parameters of horticultural products. Taking into account the weight factor of a separate index of competitiveness of horticultural products, on the basis of the suggested methodology, it is possible to calculate the competitiveness of both the producer and the consumer of products.

In addition to the factors taken into consideration in the investigated parameters, the general competitiveness of horticultural products is influenced by others, both external and internal factors. In our opinion, among the main factors hindering the competitiveness of domestic products are:

- a low selling price for horticultural products, which does not depend on the quality level;

- insufficient industry support from the state, science;

- lack of cooperation in horticulture;

- lack of funds, equipment, special equipment from manufacturers of products;

- imperfection of the certification process, product testing. Incompatibility of domestic quality standards to European ones;

- unstable economic and political situation in the country.

\section{References}

Shestopalj, O., \& Jermakov, O. 1998. Organizational and economic factors of adaptation of gardening to the market (Orghanizacijnoekonomichni chynnyky adaptaciji sadivnyctva do rynku), Gardening, 47: 257-260 (in Ukrainian).

Statistic Service of Ukraine (2017) Ploshchi, valovi zbory ta urozhainist kultur, plodiv, yahid ta vynohradu u 2016 rotsi (Squares, gross production and yields of crops, fruits, berries and grapes in 2016 year), Kyiv: Derzhavna sluzhba statystyky Ukrainy (in Ukrainian).

Kondratenko, T., \& Ghoncharuk, U. 2017. Peculiarities of fruiting and taste quality of fruit of the new generation of apple varieties immunized to the scallop in the conditions of the forest-steppe of Ukraine (Osoblyvosti plodonoshennja ta smakovi jakosti plodiv imunnykh do parshi sortiv jabluni novogho pokolinnja v umovakh Lisostepu Ukrajiny). In Selection-genetic science and education (p. 145 - 146). Uman: Uman National University of Horticulture (in Ukrainian).

Ruliev, V. 2007. The Competitiveness of Fruits and Berries: Monograph (Konkurentospromozhnistj plodiv i jaghid: monoghrafija). Melitopol: MMD (in Ukrainian). 


\section{ENTREPRENEURSHIP AND SUSTAINABILITY ISSUES}

ISSN 2345-0282 (online) http://jssidoi.org/jesi/

2019 Volume 6 Number 4 (June)

http://doi.org/10.9770/jesi.2019.6.4(3)

Kushniruk, V., Ermakov, O. \& Shebanina, O. 2009. Organizational and economic mechanism of effective gardening in agrarian enterprises of the region: Monograph (Orghanizacijno-ekonomichnyj mekhanizm efektyvnogho vedennja sadivnyctva $\mathrm{v}$ aghrarnykh pidpryjemstvakh reghionu: Monoghrafija). Mykolajiv: MDAU (in Ukrainian).

Shestopalj, O., Kondratenko, P \& Barabash, L. 2008. Theoretical and methodological foundations (the new paradigm) and components of the National Program for the Advancement of Industrial Horticulture in Ukraine: Macroeconomic Aspect: Monograph (Teoretykometodologhichni osnovy (nova paradyghma) ta skladovi Nacionaljnoji proghramy postupu promyslovogho sadivnyctva Ukrajiny: makroghaluzevyj aspekt: monoghr.). Kyiv: NNC IAE (in Ukrainian).

Gutorova, O. \& Sherstyuk, S. 2013. Marketing strategy of gardening development: theoretical and applied aspect: Monograph (Marketynghova strateghija rozvytku sadivnyctva: teoretyko-prykladnyj aspekt: monoghrafija). Kharkiv: KhNAU (in Ukrainian).

Karpenko, V., Burliai, A., Burliai, O. \& Mostovyak, M. 2016. Ukrainian garden trends under globalization, Economic Annals - XXI, 161 (9-10): 51-55. http://dx.doi.org/10.21003/ea.V161-12

Ruliev, V. 2004. Economic problems of Ukrainian horticulture development: Monograph (Ekonomichni problemy rozvytku sadivnyctva Ukrajiny). Kyiv: NNC IAE (in Ukrainian).

Kondratenko, T, Kondratenko, P. \& Chyzh, O. 1999. Stability of young trees of perspective apple varieties to low temperatures in the autumn-winter period (Stijkistj molodykh derev perspektyvnykh sortiv jabluni do nyzjkykh temperatur v osinnjo-zymovyj period), Gardening, 48: 184-189 (in Ukrainian).

Puškarić, A., Jeločnik, M. \& Ivanović, L. 2009. Analysis of Vegetable Production in the European Union with Retrospection on the Conditions in Republic of Serbia, BULETINUL Universităţii Petrol - Gaze din Ploieşti, 3, 36-43. Retrieved from http://bulletin.upgploiesti.ro/toc.jsp?page=1287\&pageType=SEc\&language $=2$.

Broeck, G. \& Maertens, M. 2016. Horticultural exports and food security in developing countries, Global Food Security, 10, 11-20. https://doi.org/10.1016/j.gfs.2016.07.007

Godoy-Durán A., Galdeano- Gómez E., Pérez-Mesa J. \& Piedra-Muñoz L. 2017. Assessing eco-efficiency and the determinants of horticultural family-farming in Southeast Spain, Journal of Environmental Management, 204 (1), 594-604. http://dx.doi.org/10.1016/j.jenvman.2017.09.037

Jablonska, J., Filipiak, T. \& Gunerka, L. 2017. Cost competitiveness of horticultural farms in Poland and selected EU countries. (Konkurencyjność kosztowa gospodarstw ogrodniczych w Polsce i wybranych krajach UE). https://doi.org/10.22630/PRS.2017.17.1.6.

Pearcea, D., Dorab, M., Wesanaac, J., \& Gellyncka X. 2018. Determining factors driving sustainable performance through the application of lean management practices in horticultural primary production, Journal of Cleaner Production 203: 400-417. https://doi.org/10.1016/i.jclepro.2018.08.170

Shumpeter, J.A. 1983. The Theory of Economic Development: An Inquiry into Profits, Capital, Credit, Interest and the Business Cycle. New Brunswick and London: Fransaction Publishers.

Porter M. 1987. From Competitive Advantage to Corporate Strategy, HBR.

The Global Competitiveness $\quad$ Report $\quad 2018 . \quad$ Retrieved http://www3.weforum.org/docs/GCR2018/05FullReport/TheGlobalCompetitivenessReport2018.pdf

Statistical bulletins: Harvest of crops, fruits, berries and grapes in the regions of Ukraine, 2011-2017. State Statistics Service of Ukraine. Retrieved from http://www.ukrstat.gov.ua

Statistical bulletin 2017: Costs for the production of agricultural products in agricultural enterprises for 2016. State Statistics Service of Ukraine. Retrieved from http://www.ukrstat.gov.ua.

Cicco, A. 2016. The fruit and vegetable sector in the EU - a statistical overview. Retrieved from http://ec.europa.eu/eurostat/statisticsexplained/index.php/The_fruit_and_vegetable_sector_in_the_EU__a_statistical_overview.

Apple season-2017/18 in Ukraine: a test of bad weather and new realities. Results of the seventh international conference "Apple Business of Ukraine-2017". Retrieved from https://www.fruit-inform.com/ru/Summary/174889\#.WwJ1Jx9oPDc 


\section{ENTREPRENEURSHIP AND SUSTAINABILITY ISSUES}

ISSN 2345-0282 (online) http://jssidoi.org/jesi/

2019 Volume 6 Number 4 (June)

http://doi.org/10.9770/jesi.2019.6.4(3)

YAO Yuchen, Jiang Fangtao, Zhang Li. 2013. Study on quality control of modern agricultural supply chain based on food safety. Retrieved from

https://scholar.google.com.au/scholar?hl=en\&as_sdt=0\%2C5\&q=.+YAO+Yuchen\%2C+Jiang+Fangtao\%2C+Zhang+Li.+Study+on+qualit y+control+of+modern+agricultural+supply+chain+based+on+food+safety\&btnG

Shpichak, O. M. 2010. Quality and price of agricultural products. (Jakistj i cina siljsjkoghospodarsjkoji produkciji). Scientific Bulletin of NUBiP of Ukraine, 154 (1), 11-19 (in Ukrainian).

CAC 2005: Understanding the Codex Alimentarius. World Health Organisation (WHO) and Food and Agriculture Organization of the United Nations (FAO) Rome. Revised and updated 2005. Retrieved 2005, from http://www.fao.org/docrep/008/y7867e/y7867e00.htm

ISO 22000:2018. Food safety management systems — Requirements for any organization in the food chain.

Verkhovna Rada of Ukraine. 1998. Basic Principles and Requirements for the Safety and Quality of Food Products: Law of Ukraine. Retrieved from http://zakon.rada.gov.ua/laws/show/771/97-вp (in Ukrainian).

George, R., Beine J., Arnold U. Resource configurations, product development capability, and competitive advantage: An empirical analysis of their evolution, Journal of Bisiness Reseach, 85, 32-50. https://doi.org/10.1016/j.jbusres.2017.11.045

Kondratenko, T.E. 2000. Immune varieties and their role in improving the assortment of apple in Ukraine (Imunni sorty ta jikh rolj $\mathrm{v}$ udoskonalenni sortymentu jabluni v Ukrajini). Gardening, 51: 28 - 34 (in Ukrainian).

Short biographical note about the contributors at the end of the article (name, surname, academic title and scientific degree, duties, research interests):

Olena BOHDANIUK is the Associate Professor of Department of Statistics and Economic Analysis, Candidate of Economic Sciences, National University of Life and Environmental Sciences of Ukraine, Kyiv, Ukraine.

Research interests: horticulture, analytical-prognostic modeling, quality and safety of food, competitiveness of products.

ORCID ID: $\underline{\text { orcid.org/0000-0002-8354-9933 }}$

Ruslan BURIAK is the professor of marketing and international trade department, doctor of economic sciences, National University of Life and Environmental Sciences of Ukraine, Kyiv, Ukraine.

Research interests: marketing activities of enterprises of agrarian sector, quality management

ORCID ID: orcid.org/0000-0002-2988-2196

Vasyl SAVCHUK is the Professor of Department of Statistics and Economic Analysis, Doctor of Economics Sciences, National University of Life and Environmental Sciences of Ukraine, Acting Head of the Department of Statistics and Economic Analysis, Kyiv, Ukraine.

Research interests: analytical and forecast aspects, strategic decisions, agrarian enterprises.

ORCID ID: orcid.org/0000-0002-4261-3329

Copyright (C) 2019 by author(s) and VsI Entrepreneurship and Sustainability Center

This work is licensed under the Creative Commons Attribution International License (CC BY).

http://creativecommons.org/licenses/by/4.0/

CC) (i) Open Access 